\title{
EFEK NIGELLA SATIVA OIL TERHADAP UKURAN DIAMETER ULKUS TRAUMATIKUS PADA MALE WISTAR RATS SECARA IN VIVO
}

Linda Septiana ${ }^{\star}$, Ratnawati Hendari**, Erwid Fatchur Rahman ${ }^{*}$ Diyah Fatmasari ${ }^{* *}$

Keywords: Nigella sativa Oil, reduction of diameter, traumatic ulcer

\section{ABSTRACT}

Background: Ulcer is a pathological condition characterized by loss of epithelial tissue. Ulcer will experience healing within 2 weeks after trauma source is removed. Nigella sativa Oil has been known to heal wounds. The purpose of this study was to evaluate the effect of NSO on healing of ulcers in male wistar rats from the use of chemicals.

Method: This study design was quasi-experimental methods. Ten male wistar rats were exposing the $\mathrm{H} 2 \mathrm{O} 2$ on the mandibular anterior gingiva. divided into negatif control group and NSO group. NSO group treated twice daily for 10 days. Observaton wound size was measured on 0, 3,7, 10 days. The results were analayzed with Repeated Anova test and LSD test.

Result: The observations difference diameter of traumatic ulcer negative control group and NSO on 0-10 days was $1.458 \mathrm{~mm}$ and $2.182 \mathrm{~mm}$. The results of data analysis showed that there are significant differences $(p<0,05)$ between negatif control group and NSO.

Conclusion: NSO has an influence of the size reduction of the diameter of traumatic ulcers.

\section{PENDAHULUAN}

Ulkus merupakan keadaan patologis yang ditandai dengan hilangnya jaringan epitel. ${ }^{1}$ Ulkus traumatikus memiliki gambaran histologi kerusakan lapisan basal dari epitel. ${ }^{2}$ Trauma fisik dan kimia merupakan penyebab terjadinya ulkus di mukosa mulut. Trauma kimia dapat disebabkan oleh bahan kedokteran gigi seperti obat kumur berkadar alkohol tinggi, eugenol dan hidrogen peroksida. Ulkus traumatikus mempunyai gambaran klinis berupa dasar lesi yang kekuningan, eritematus, soliter, ukuran diameter bervariasi tergantung besarnya trauma dan berbentuk bulat. Ulkus akan mengalami kesembuhan dalam waktu 2 minggu setelah sumber trauma dihilangkan. ${ }^{1}$

Nigella sativa oil (NSO) telah dikenal dan digunakan beberapa negara karena memiliki efek menyembuhkan. NSO selain memiliki efek menyembuhkan juga dalam penggunaanya tidak ditemukan efek alergi dan toksin. ${ }^{3}$ NSO mempunyai kandungan utama thymoquinone (TQ). Kanter dkk ${ }^{4}$ menyatakan TQ dalam NSO dapat menyembuhkan ulserasi di mukosa lambung akibat konsumsi alkohol.

NSO juga memiliki efek anti-ulcerogenic pada mukosa lambung dengan meningkatkan produksi mucin. ${ }^{4}$ Berdasarkan alasan tersebut peneliti ingin meneliti lebih lanjut tentang penggunaan NSO sebagai medikamen terhadapulkustraumatikusakibatbahankimiawi mencari alternatif dengan menggunakan obat herbal untuk menyembuhkan ulkus traumatikus akibat terkena bahan kimia pada mukosa mulut. Male wistar rats dipilih karena memiliki organ, hormon, sistem saraf, reaksi tubuh terhadap infeksi yang hampir sama seperti manusia. ${ }^{5}$

* Staff Pengajar Fakultas Kedokteran Gigi Universitas Islam Sultan Agung, ** Staff Pengajar JKG Poltekkes Kemenkes Semarang

Korespondensi: septiana.linda5@gmail.com 


\section{METODE PENELITIAN}

Jenis penelitian yang digunakan adalah kuasi eksperimental, dengan rancangan the pre-post test Control Group Design. Terdapat 2 kelompok, kelompok kontrol negatif dan

kelompok NSO. Setiap kelompok terdiri atas 5 male wistar rats sesuai perhitungan WHO. Male wistar rats diadaptasikan selama 1 minggu. Gingiva tikus rahang bawah dipaparkan $\mathrm{H} 2 \mathrm{O} 2$ konsentrasi $3 \%$ selama 2 hari menggunakan cotton bud. Frekuensi pemaparan 3 kali sehari selama 90 detik. Setelah 90 detik diirigasi dengan aquades. Setelah 2 hari pemaparan $\mathrm{H} 2 \mathrm{O} 2$, tikus dibiarkan dalam kandang selama 48 jam. Setelah 48 jam perlukaan tikus diukur menggunakan jangka sorong digital.

Kelompok pertama tidak diberikan perlakuan, kelompokkedua diberikan perlakuan NSO. NSO dalam penelitian ini didapat dari hasil destilasi dengan konsentrasi 100\%. NSO diberikan setiap 2 kali sehari sebanyak $0,02 \mathrm{ml}$ dengan interval 12 jam selama 10 hari. $^{6}$ Pengukuran ulkus dilakukan pada hari 0 , 3,7 , dan 10. Pencatatan dan analisa data.

\section{HASIL PENELITIAN}

Rata-rata pengukuran ulkus traumatikus pada hari ke-0, 3, 5 dan 10 yang ditampilkan pada tabel 1.

Tabel 1. Hasil rata-rata pengukuran diameter ulkus traumatikus kelompok kontrol negatif dan kelompok NSO

\begin{tabular}{ccc}
\hline Hari ke- & $\begin{array}{c}\text { Kontrol negatif } \\
(\mathrm{mm})\end{array}$ & NSO $(\mathrm{mm})$ \\
\hline 0 & 3,564 & 4,172 \\
3 & 4,42 & 4,38 \\
7 & 3,22 & 2,27 \\
10 & 2,078 & 1,99 \\
\hline
\end{tabular}

Hari ke-3 semua kelompok mengalami pembesaranukurandiameterulkustraumatikus. Hari ke-7 dan 10 semua kelompok mengalami pengecilan ukuran ulkus traumatikus. Hari ke-7 dan ke-10 kelompok NSO memilki ukuran diameter ulkus traumatikus paling kecil. Kelompok kontrol negatif memiliki ukuran diameter ulkus traumatikus paling besar..

Tabel 2. Hasil uji T Tidak Berpasangan ukuran diameter ulkus traumatikus hari ke-0

\begin{tabular}{lccc}
\hline & Df & $\mathrm{t}$ & Sig. \\
\hline Equal variances not assumed & 4.689 & -2.341 & 0,07 \\
\hline
\end{tabular}

Rerata ukuran diameter ulkus traumatikus pada hari ke-0. menunjukkan bahwa tidak ada perbedaan yang bermakna. Maksudnya adalah pada hari ke-0 awal pembuatan ulkus, ukuran diameter ulkus traumatikus dinyatakan tidak berbeda secara statistik, hal ini ditandai dengan $p>0,05$.

Tabel 3. Hasil rata-rata selisih perubahan ukuran diameter ulkus traumatikus

\begin{tabular}{ccc}
\hline Hari ke- & Kontrol negatif (mm) & NSO (mm) \\
\hline $0-3$ & $-0,658$ & $-0,106$ \\
$0-7$ & 0,344 & 1,902 \\
$0-10$ & 1,486 & 2,182 \\
\hline - = Ukuran diameter ukuran ulkus traumatikus membesar \\
$+=$ Ukuran diameter ukuran ulkus traumatikus mengecil
\end{tabular}

Berdasarkan tabel 3 semua kelompok pada hari 0-3 mengalami pembesaran ukuran diameter ulkus traumatikus. Hari 0-7 dan 0-10 semua kelompok mengalami pengecilan ukuran diameter ulkus traumatikus. Selisih perubahan ukuran diameter ulkus traumatikus terbesar terlihat pada kelompok NSO. Selisih perubahan ukuran diameter ulkus traumatikus terkecil terlihat pada kelompok kontrol negatif.

Data hasil selisih perubahan perkembangan 
diameter ulkus diatas kemudian di analisa normalitas dan homogenitas. Hasil analisa menunjukkan data normal dan homogen. Prasyarat uji parametrik terpenuhi, maka mengetahui untuk perbedaan antar kolompok menggunakan parametrik yaitu Uji Repeated Anova (tabel 4).

Tabel 4. Hasil analisis statistik uji Repeated Anova pada kelompok kontrol negatif dan NSO

\begin{tabular}{cccccc}
\hline & Tipe III Kuadrat & df & Rerata & F & Sig. \\
\hline Intercept & 17,572 & 1 & 17,572 & 11,629 & 0,008 \\
Error & 13,599 & 9 & 1,511 & & \\
\hline
\end{tabular}

Hasil uji statistik Repeated Anova (tabel 4) menunjukkan bahwa ada perbedaan yang bermakna $(p<0,05)$. Hal tersebut mempunyai arti ada perbedaan yang bermakna dalam perubahan ukuran ulkus traumatikus antar kelompok. Uji LSD digunakan untuk mengetahui perbedaan antara kelompok mana saja yang memiliki perbedaan (tabel 5).

Tabel 5. Hasil analisis statistik uji LSD perbandingan antara kelompok kontrol negatif dan NSO

\begin{tabular}{ccc}
\hline Kelompok & Kontrol negatif & $\mathrm{NSO}$ \\
\hline $\begin{array}{c}\text { Kontrol negatif } \\
\text { NSO }\end{array}$ & $0,000^{*}$ & $0,000^{*}$ \\
\hline
\end{tabular}

Uji LSD menunjukkan terdapat perbedaan yang bermakna $(p<0,05)$. Hal tersebut memiliki arti ada perbedaan perubahan ukuran diameter ukus traumatikus antar kelompok yaitu kelompok kontrol negatif dengan NSO.

\section{DISKUSI}

Penelitian ini dilakukan untuk mengetahui efek NSO terhadap ukuran diameter ulkus traumatikus pada male wistar rats. Hasil penelitian menunjukkan pembesaran ukuran diameter ulkus traumatikus pada hari-3 (tabel 1). Hal ini kemungkinan karena agen penyebab inflamasi yang masih tertinggal di ulkus. Agen penyebab inflamasi pada penelitian ini adalah bahan kimiawi H2O2. Inflamasi kronik muncul apabila inflamasi akut tidak berhasil melenyapkan agen penyebab inflamasi, sehingga menyebabkan kerusakan jaringan. ${ }^{7}$

Kerusakan jaringan menyebabkan migrasi leukosit ke daerah inflamasi. Migrasi leukosit ke daerah inflamasi akibat dari produksi leukotrien pada daerah inflamasi. ${ }^{8}$ Leukotrien memberikan signal kepada leukosit. ${ }^{9}$ Leukosit akan terkumpul di daerah inflamasi. Leukosit akan menfagosit agen penyebab inflamasi. ${ }^{10}$ Demikian juga dari penelitian Duarte $\mathrm{dkk}^{6}$, bahwa pada hari ke-3 ulkus terdapat inflamasi yang hebat. $^{6}$ Inflamasi terjadi ketika sel mast memicu terjadinya metabolisme asam arakhidonat. Metabolisme asam arakhidonat menghasilkan mediator inflamasi seperti histamin. Histamin menyebabkan peningkatan permeabilitas pembuluh darah. Peningkatan permeabilitas pembuluh darah dalam jaringan menyebabkan terjadinya odem. ${ }^{11}$

Proses inflamasi akan berhenti ketika agen penyebab inflamasi hilang. Kelompok NSO memilki ukuran diameter ulkus traumatikus paling kecil. NSO memilki kemampuan meminimalkan agen penyebab inflamasi pada ulkus. Agen penyebab inflamasi yang minimal akan mempercepat kesembuhan ulkus. ${ }^{3}$

Hasil uji T Tidak Berpasangan (tabel 2), bahwa pada hari ke-0 awal pembuatan ulkus, ukuran diameter ulkus traumatikus dinyatakan tidak berbeda secara statistik. Ukuran diameter ulkus traumatikus dinyatakan tidak berbeda karena peneliti mengontrol kedalaman luka, lebar ukuran diameter, dan waktu pemaparan.

Hari ke-7 dan 10 semua kelompok mengalami pengecilan ukuran ulkus traumatikus (tabel 1). Pengecilan ukuran diameter ulkus traumatikus disebablan karena 
fase inflamasi selesai. Fase selanjutnya adalah fase proliferasi. Fase proliferasi terjadi proses granulasi dan kontraksi pada ulkus. Proses granulasi ditandai dengan proliferasi fibroblas yang membentuk jaringan baru. Proses konstraksi ditandai dengan migrasi kolagen. Migrasi kolagen disekitar ulkus menyebabkan ukuran ulkus mengecil. ${ }^{12}$

Kelompok NSO memliki selisih ukuran diameter ulkus traumatikus paling besar pada hari 0-7 dan 0-10 (tabel 3). Selisih ukuran diameter ulkus traumaikus paling besar menandakan kecepatan pengecilan ukuran diameter ulkus. Pengecilan ukuran diameter ulkus traumatikus kelompok NSO lebih cepat. Pengecilan ukuran diameter ulkus traumatikus kelompok NSO lebih cepat karena tahap inflamasi berlangsung lebih cepat. Hal ini karena kandungan TQ dalam NSO sebagai anti-inflamasi yang dapat mengefektifkan kerja leukotrien. $^{3}$ Pengefektifan kerja leukotrien menyebabkan proses inflamasi terkontrol, sehingga meminimalkan kerusakan jaringan. Pengaruh NSO terhadap ukuran diameter ulkus traumatikus pada male wistar rats dapat dilihat pada hasil perhitungan statistik Repeated Anova yang menunjukkan nilai $p<$ 0,05 (tabel 5).

\section{KESIMPULAN}

Kelompok kontrol negatif memilki pengaruh dalam memperkecil ukuran diamter ulkus traumatikus sebesar $1,48 \mathrm{~mm}$ $(41,5 \%)$. Kelompok NSO memiliki pengaruh dalam memperkecil ukuran diameter ulkus traumatikus sebesar 2,18 $\mathrm{mm} \quad(52,3 \%)$. Kelompok NSO memiliki pengaruh yang lebih baik dalam memperkecil ukuran ulkus traumatikus dibandingkan kelompok kontrol negatif.

\section{DAFTAR PUSTAKA}

1. Birnbaum, Warren. dan Dunne Stephen, M. 2010. Diagnosis Kelainan Dalam Mulut. Penerjemah : Hartono Ruslijanto, drg dan Enny M R, drg. EGC. Jakarta . Hal. 245-246.

2. Langlais, Robert.P. 2000. Atlas Berwarna Kelainan Rongga Mulut Yang Lazim. Penerjemah : Budi Susetyo, drg. Hipokrates. Jakarta. Hal. 94.

3. Al-Douri, Asmaa.S. dan Al-Kazaz, S. G. A. 2010. The Effect of Nigella sativa Oil (Black Seed) on the Healing of Chemically Induced Oral Ulcer in Rabbit (Experimental Study). J.Al-Rafidain Dent J. 10:151157.

4. Kanter, Mehmet., Demir, Halit., Karakaya, Cengiz, dan Ozbek, Hanefi. 2005. Gastroprotective Activty of Nigella sativa L Oil and Its Constituent, Thymoquinon Against Acute Alcohol-Induced Gastric Mucosal Injury in Rat. J. of World Journal of Gastroenterology.11(42):6662-6666.

5. Don, Glass. 2003. How Human are Like Rats. Diakses 20 April 2012 dari http://indianapublicmedia. org/amomentofscience/how-humans-are-like-rats/

6. Duarte, C.M.E., Quirino, M.R.S., Patrocinio. M. C., dan Anbinder, A. L. 2011. Effect Of Chamomilla Recucita (L.) On Oral Wound Healing In Rats. J. of Oral Medicine And Pathology. 1;6 (6): e 716-721.

7. Baratawidjaja, KG dan Rengganis, Iris. 2009. Imunologi Dasar. Fakultas Kedokteran Universitas Indonesia. Jakarta. Hal 277-279.

8. Marks, DB., Marks, AD dan Smith, CM. 2000. Bikokimia Kedokteran Dasar. EGC. Jakarta. Hal 540.

9. Robbins, ST., Cotran, RS dan Kumar, Vinay. 2010. Intisari Patologi. Binarupa Aksara. Tangerang. Hal 17.

10. Peterson, L.J., Ellis, E., Hupp, J.R, dan Tucker, M.R. 2003. Contemporary Oral and Maxillofacial Surgery (4th ed). Mosby. Missouri. Hal 49-52.

11. Roitt, Ivan M., Burton, Dennis R., Martin, Seamus J dan Delves, Peter, Peter J. 2011. Roitt's Essential Immunology (12thed). Wiley-Blackwell. Singapura. Hal 21-22.

12. Suriadi. 2004. Perawatan Luka. Sagung Seto. Jakarta. Hal 7-11.

13. Van Zyl, AW dan Van Heerdenm,WFP. 2010. Mouthwash : A Review for South African Health Care Workers. J. of CPD. Vol 52. 